Сергій Мотика,

Військовий інститут Київського національного університету імені Тараса Шевченка

ORCID ID 0000-0001-6423-7697

\title{
МОДЕЛЬ ВИХОВАННЯ ПАТРІОТИЗМУ УЧНІВСЬКОЇ МОЛОДІ В УМОВАХ ВІЙСЬКОВОГО ЛІЦЕЮ
}

У статті розглядається зміст моделі виховання патріотизму учнівської молоді в умовах військового ліщею, а саме - такої моделі, яка базуватиметься на відповідних концепціях, підходах, принщипах освіти та педагогічних умовах на основі изього формування змісту, форм методів виховання патріотизму, а також створення патріотичного середовища. Пропонуються напрями перспективних досліджень із зазначеної проблематики.

Ключові слова: модель; патріотизм; патріотичне виховання; любов до Батьківщини; ліщееїсти; зміст.

Однією з основ захисту суверенітету, територіальної цілісності нашої держави є патріотизм учнівської молоді в умовах військового ліцею. Нині в Україні все більшої актуальності набуває виховання в учнівської молоді в умовах військового ліцею почуття патріотизму, що спричинене новими суспільно-політичними реаліями в нашій державі після Революції гідності; обставинами, пов'язаними з російською агресією.

Фундаментальне значення для виховання патріотизму учнівської молоді в умовах військового ліцею має системне використання даних усіх наук про людину як мету виховання i ïх врахування у плануванні та здійсненні виховання патріотизму. Водночас цей підхід забезпечує отримання вірогідного емпіричного матеріалу та його обробку і включення в наукове знання.

Проблема виховання патріотизму учнівської молоді є предметом цілої низки дисертаційних досліджень і наукових праць українських вчених (I. Бех, М. Боришевський, В. Івашковський, Р. Петронговський, Ю. Руденко, О. Сухомлинська, К. Чорна та ін.). Важливим також $є$ роботи 3 теорії та практики формування патріотизму у військовослужбовців Збройних Сил України (А. Афанасьєва, В. Дзюба, Ю. Красильника, Р. Кутового, В. Мірошніченко, Л. Олійника та інших). Водночас дослідження, присвячені безпосередньо вихованню патріотизму військових ліцеїстів не були предметом наукових досліджень в Україні.

Метою статті $\epsilon$ висвітлення педагогічних умов як основи моделі виховання патріотизму учнівської молоді в умовах військового ліцею, яка базується на відповідних меті, підходах, принципах, змісті, педагогічних умов, критеріїв та очікуваного результату

Виховання патріотизму учнівської молоді в умовах військового ліцею це процес цілеспрямованого систематичного формування почуття патріотизму, духовної та психологічної готовності до виконання 
громадянського і конституційного обов'язку щодо захисту суверенітету, територіальної цілісності держави.

У ході формувального етапу експериментальної роботи було вирішено такі завдання: апробовано експериментальну модель виховання патріотизму учнівської молоді в умовах військового ліцею; встановлено ефективність реалізації запропонованих педагогічних умов виховання патріотизму учнівської молоді в умовах військового ліцею; визначено рівень сформованості патріотичної вихованості учнівської молоді в умовах військового ліцею.

Модель виховання патріотизму учнівської молоді в умовах військового ліцею (рис. 1) у нашому дослідженні містить наступні компоненти: цільовий (мета), концептуальний (підходи, принципи та функції виховання патріотизму учнівської молоді в умовах військового ліцею), змістовий компонент, операційно-технологічний (педагогічні умови виховання патріотизму учнівської молоді в умовах військового ліцею й методика реалізації педагогічних умов) та результативний компонент.

Цільовий компонент структури моделі виховання патріотизму учнівської молоді в умовах військового ліцею $є$ системоутворювальним та визначає функціонування всіх інших компонентів моделі.

Концептуальний компонент розробленої моделі виховання патріотизму учнівської молоді в умовах військового ліцею складають наступні підходи. Системний підхід нами застосовано для аналізу усіх чинників, відбір найбільш доцільних методів та прийомів, які спрямовано на організацію процесу з національно-патріотичного виховання ліцеїстів.

Видатний психолог О. Леонтьєв підкреслив, що дослідження процесу народження i трансформації особистості - в іiі діяльності, яка протікає в конкретних умовах, і $€$ ключем до іiі істинно наукового психологічного розуміння [4, с. 173].

Особистість учня в умовах військового ліцею не може розглядатися за межами національного. В зв'язку 3 цим культурологічний підхід трансформується в етнопедагогічний, який застосовується в єдності загальнолюдського, національного та індивідуального. В зв'язку з цим культурологічний підхід трансформується в етнопедагогічний, який застосовується в єдності загальнолюдського, національного та індивідуального. К. Ушинський наголошував на тому, що характер виховання відповідає характеру народу, і важаючи на стійкість і органічність національного в людині, він радить вихователю взяти національне за основу системи виховання: “Як немає людини без самолюбства, так немає людини без любові до батьківщини, і ця любов дає вихованню надійний ключ до серця людини і могутню опору для боротьби з іï поганими природними, особистими, сімейними і родовими нахилами... " [5, с. 99-100]. 
META: Виховання патріотизму учнівської молоді в умовах військового ліцею

Концепція виховання патріотизму учнівської молоді в умовах військового ліцею

Підходи (системний, особистісно-орієнтований, культурологічний, антропологічний, аксіологічний)

Зміст виховання патріотизму учнівської молоді в умовах військового ліцею: патріотична свідомость, комплекс професійних й особистісних якостей (морально-політичних, громадянських, військово-професійних, соціальнопсихологічних, психічних, фізичних), психологічна, загальновійськова та фізична готовність діяльності

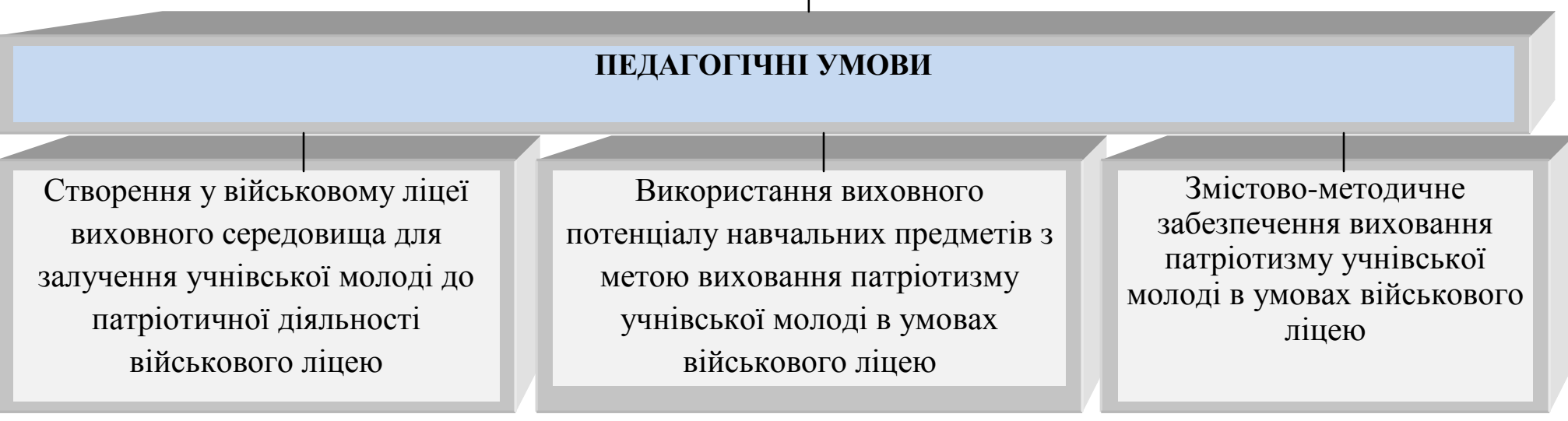

Критерії патріотичної вихованості: пізнавальний, ціннісно-мотиваційний, результативно-поведінковий

\section{Рівні патріотичної вихованості: низький, середній, високий}

Результат: підвищення рівня патріотичної вихованості учнівської молоді

Рис. 1. Модель виховання патріотизму учнівської молоді в умовах військового ліцею 
Реалізація вищеозначеного здійснюється у зв'язку з культурологічним підходом, який обумовлює соціально-гуманістичну програму i визначає спрямованість різновиду діяльності особистості.

Фундаментальне значення для виховання патріотизму учнівської молоді в умовах військового ліцею має обгрунтований К.Ушинским антропологічний підхід - системне використання даних всіх наук про людину як мету виховання i ïx врахування у плануванні та здійсненні процесу військово-патріотичного виховання. Видатний педагог наголосив: якщо педагогіка хоче виховати людину в усіх відношеннях, то вона повинна перш за все пізнати іiї в усіх відношеннях.

Роль механізму зв'язку між практичним та пізнавальним підходами виконує реалізація ціннісного підходу до виховання патріотизму учнівської молоді в умовах військового ліцею. Система цінностей слугує фундаментом виховання особистості. О. Вишневський обгрунтовує п'ять груп цінностей, взявши за критерій їх сферу застосування: а) особистого життя людини (особисті цінності), б) родинного життя (цінності сімейного життя), в) сфери суспільно-громадських стосунків (громадянські цінності), г) національно-державного життя (національні цінності), д) життя всього людства (абсолютні вічні цінності) [2, с. 87].

Таким чином, в структурі концептуального компоненту виховання патріотизму учнівської молоді в умовах військового ліцею необхідно виділити культурологічний, антропологічний та аксіологічний підхід, які утворюють складну систему, в рамках якої існує відповідне підпорядкування.

До принципів на основі теоретичного аналізу проблем виховання патріотизму учнівської молоді в умовах військового ліцею необхідно віднести: гуманізації, культурно-історичної суб'єктності, ціннісної орієнтації, єдності навчання і виховання.

Змістовий компонент $\epsilon$ найважливішим у моделі патріотичного виховання студентів. Філософська категорія «зміст» означає визначаючий бік цілого, сукупність його частин. Зміст розглядається у єдності та протилежності з формою як засобом існування й виявлення змісту.

На відміну від поняття «зміст освіти», категорія «зміст виховання» $є$ у педагогіці недостатньо розробленою; наявними є суттєві тлумачення у визначенні того, що саме слід відносити до галузі змісту виховання.

За своїм характером процес виховання - надзвичайно складне соціально-педагогічне явище, тому вимагає з боку вихователів опанувати як теоретично-методичні підвалини військового виховання, так i оволодіти конкретними навичками та умінням організації й проведення виховного процесу в підрозділі [6, с. 308].

Зважаючи на особливості організації виховного процесу на рівні підрозділу учнівської молоді в умовах військового ліцею доцільно зазначити, що О. Дубасенюк дає визначення: «виховна діяльність - це взаємодія педагога-вихователя 3 учнями, що цілеспрямована на самостановлення, саморозвиток, самовиховання молодої людини, яка реалізується шляхом 
розв'язання множини виховних завдань i забезпечує формування особистісних, соціально значущих морально-етичних цінностей, норм та правил поведінки» [3]. На цьому рівні виховувати - це дійсно проектувати поступове становлення якостей особистості учня військового ліцею (траєкторій професійного росту, вдосконалення патріотизму тощо).

Науковець С. Вершиловський з цього приводу наголошує, що «виховна діяльність потребує проникнення в онтологію буття іншої людини, інтеракцію особистостей вихователя і вихованця, взаємопроникнення їх сфер життедіяльності» [1, с. 49].

До змістового компоненту виховання патріотизму учнівської молоді в умовах військового ліцею входять наступні складники: патріотична свідомость, комплекс професійних й особистісних якостей (моральнополітичних, громадянських, військово-професійних, соціальнопсихологічних, психічних, фізичних), психологічна, загальновійськова та фізична готовність.

Операційно-технологічний компонент влючив педагогічні умови виховання патріотизму учнівської молоді в умовах військового ліцею як сукупність причин, обставин, чинників, що впливають на визначений процес та можуть його прискорювати чи уповільнювати, впливаючи цим самим на кінцевий результат.

Створення у військовому ліцеї виховного середовища повинно забезпечити розкриття в учня потенціалу патріотичної вихованості та запустити його механізми. Важливим аспектом реалізації цієї педагогічної умови можна вважати заходи координуючого характеру, зокрема залучення учнівської молоді до видів патріотичної діяльності військового ліцею.

Використання виховного потенціалу навчальних предметів 3 метою виховання патріотизму учнівської молоді в умовах військового ліцею зумовлений тим, що виховання патріотизму учня здійснююється переважно у процесі навчально-пізнавальної діяльності шляхом внесення ціннісних складових у зміст навчальних предметів (української мови та літератури, історії України, української культури, географії, захист Вітчизни та інші).

Щодо третьої умови, як змістово-методичного забезпечення виховання патріотизму учнівської молоді в умовах військового ліцею зазначимо, що іï реалізація передбачала розроблення комплексу навчальних та спеціальних програм i методик щодо організації та проведення заходів виховання патріотизму учнівської молоді в умовах військового ліцею в їі різноманітних формах, використання всієї багатоманітності педагогічних форм і засобів 3 урахуванням особливостей життєдіяльності учнів; регулярне видання відповідної літератури, що висвітлює цю сферу діяльності 3 урахуванням інновацій, передового навчально-виховного досвіду.

Результативний компонент включав критерії патріотичної вихованості: пізнавальний, ціннісно-мотиваційний, результативно-поведінковий, які визначали рівень сформованості патріотичної вихованості учня військового ліцею. 
Отже, сформована патріотична вихованість розглядається нами як результат засвоєння учнівської молоді в умовах військового ліцею досвіду пізнавальної діяльності, емоційно-цінних відносин та дійово-практичного досвіду, які виявляються у здатності та готовності реалізуватися як особистість та індивідуальність у діяльності на благо Батьківщини.

Структура патріотичної вихованості учнівської молоді в умовах військового ліцею відображена у таблиці 1.1.

Таблиця 1.1.

Компоненти, критерії та показники патріотичної вихованості учнівської молоді в умовах військового ліцею

\begin{tabular}{|c|c|c|}
\hline Компоненти & Критерії & Показники \\
\hline 1 & 2 & 3 \\
\hline Когнітивний & Пізнавальний & $\begin{array}{l}\text { 1) Знання історії, культури, героїчніих } \\
\text { звершень держави. } \\
\text { 2) Здатність до аналізу процесів і явищ, } \\
\text { проблем і протиріч, властивих суспільству i } \\
\text { державі. } \\
\text { 3) Володіння державною мовою. }\end{array}$ \\
\hline $\begin{array}{l}\text { Світоглядно- } \\
\text { мотиваційний }\end{array}$ & $\begin{array}{l}\text { Мотиваційно- } \\
\text { ціннісний }\end{array}$ & $\begin{array}{l}\text { 1) Осмислення Вітчизни як вищої соціально } \\
\text { значущою, духовно-історичної та інтегрованої } \\
\text { цінності. } \\
\text { 2) Позитивна мотивація } \\
\text { українському народові та державі. } \\
\text { 3) Переконання в необхідності захисту } \\
\text { національних інтересів власної держави } \\
\text { 4) Наявність патріотичних ідеалів, як } \\
\text { регуляторів життєдіяльності учнівської молоді в } \\
\text { умовах військового ліцею. }\end{array}$ \\
\hline Діяльнісний & $\begin{array}{l}\text { Результативно- } \\
\text { поведінковий }\end{array}$ & $\begin{array}{l}\text { 1) Здатність до патріотичної самореалізації. } \\
\text { 2) Психологічна готовність. } \\
\text { 3) Фізична готовність. } \\
\text { 4) Уміння оцінювати патріотичний потенціал } \\
\text { заходів, занять. } \\
\text { 5) Уміння організовувати патріотичні заходи. }\end{array}$ \\
\hline
\end{tabular}

Виховання патріотизму учнівської молоді в умовах військового ліцею являє собою сукупність основних ознак показників, які розкривають істотні моменти, параметри, що характеризують його як процес, тобто ті способи, фактори, умови, за рахунок використання яких забезпечується найбільш повна реалізація можливостей цієї діяльності, яка здійснюється з метою досягнення бажаного (кінцевого) результату. 3 цього випливає, що, будучи одним 3 компонентів критерію, та чи інша ознака, показник з вихованості патріотизму, виступає як конкретний і типовий прояв його істотних сторін. Можна стверджувати про зв'язок і єдність критеріїв 3 патріотичної вихованості змісту, істотних сторін цієї діяльності і їі кінцевих результатів. Тому, щоб відповідати своєму призначенню, критерії 3 патріотичної вихованості, якщо мати на увазі їх змістовний аспект, повинні в значній мірі розкривати, характеризувати, виражати його суть і специфіку і в той же час бути орієнтованими, націленими на бажані результати. 
Таким чином, педагогічні умови виховання патріотизму учнівської молоді в умовах військового ліцею, які реалізують відібраний i структурований зміст в практичній формі через сукупність методів, форм і засобів і $є$ основою визначеної моделі. Усі компоненти моделі, перебуваючи у тісному взаємозв'язку та випливаючи один з одного, забезпечують реалізацію мети. Таким чином, результатом впровадження та реалізації пропонованої нами моделі є ліцеїст 3 відповідним рівнем сформованості патріотичної вихованості.

Перспективами подальшого дослідження $є$ визначення рекомендацій щодо виховання патріотизму учнівської молоді в умовах військового ліцею.

\section{ЛІТЕРАТУРА}

1. Вершиловский С. Г. Профессиональная деятельность молодого учителя: социально-педагогический аспект / С. Г. Вершиловский, Л.Н.Лесохина. - М. : Педагогіка, 1982. - 144 с.

2. Вишневський О. Концепція демократизації українського виховання //Концептуальні засади демократизації та реформування освіти в Україні: педагогічні концепції. - К.: Школяр, 1997. - С.78- 122.

3. Дубасенюк О. А. Теоретичні та методичні основи виховної діяльності педагога: дис. ... доктора пед. наук : 13.00.04. / Дубасенюк

Олександра Антонівна. - К., 1996. - 444 с.

4. Леонтьев А.Н. Деятельность. Сознание. Личность. - М.: Политиздат, 1975. - 304 с.

5. Ушинський К.Д. Теоретичні проблеми виховання і освіти //Вибр. пед. твори: У 2х т.- К.: Рад. школа, 1983.- Т. 1.- 488 с.

6. Ягупов В. Управлінські функції офіцера та їх педагогічний зміст / Василь Ягупов // Вісник Української Академії державного управління при Президентові України. - 2000. - № 2. - C. 311-314.

\section{REFERENCES}

1. Vershilovskij, S. G. (1982). Professionalnaya deyatelnost molodogo uchitelya: socialno-pedagogicheskij aspekt [Professional activity of a young teacher: a socio-pedagogical aspect]. Pedagogika, 144. (in Russian).

2. Vishnevskij, O. (1997). Koncepciya demokratizaciyi ukrayinskogo vihovannya [Concept of democratization of Ukrainian education]. Konceptualni zasadi demokratizaciyi ta reformuvannya osviti v Ukrayini: pedagogichni koncepciyi, 78- 122. (in Ukrainian).

3. Dubasenyuk, O. A. (1996). Teoretichni ta metodichni osnovi vihovnoyi diyalnosti pedagoga [Theoretical and methodological foundations of educational activity of the teacher]. Zhytomyr, 444. (in Ukrainian).

4. Leontev, A.N. (1975). Deyatelnost. Soznanie. Lichnost [Activities Consciousness Personality]. Politizdat, 304. (in Russian).

5. Ushinskij, K.D. (1983). Teoretichni problemi vihovannya i osviti [Theoretical problems of education and education]. Vibr. ped. tvori: U 2-h t. Rad. shkola, 488. (in Ukrainian).

6. Yagupov, V. (2000). Upravlinski funkciyi oficera ta yih pedagogichnij zmist [Management functions of the officer and their pedagogical content] Visnik Ukrayinskoyi Akademiyi derzhavnogo upravlinnya pri Prezidentovi Ukrayini, 311-314. (in Ukrainian). 


\section{РЕЗЮМЕ}

Сергей Мотыка,

Военный институт Киевского национального университета имени Тараса Шевченко

\section{Модель воспитания патриотизма ученической молодежи в условиях военного лицея.}

В статье рассматривается содержание модели воспитания патриотизма военных лицеистов У статті розглядається зміст моделі ученической молодежи в условиях военного лицея - модели, которая базируется на определенніх концепциях, подходах, принщипах образования и педагогических условиях на основе этого формирование содержание, форм методов воспитания патриотизма, а также образование патриотического середовища. Пропонуються напрями перспективних досліджень із зазначеної проблематики.

Предлагаются направления перспективных исследований с заявленной проблематики.

Ключевье слова: модель; патриотизм; патриотическое воспитание; любовь к Родине; лицеисты; содержание.

\section{SUMMARY}

Sergey Motyka, Military Institute of Taras Shevchenko National University of Kyiv

\section{Model of patriotic education among military lyceum students}

Introduction. One of the foundations for the protection of the sovereignty, territorial integrity of our state is the patriotism of student youth in the conditions of military lyceum. Nowadays, in Ukraine, an increasing sense of education in the pupils' youth in the conditions of the military Lyceum is the feeling of patriotism caused by new socio-political realities in our state after the Revolution of dignity; circumstances associated with Russian aggression.

Purpose. The purpose of the article is to highlight the pedagogical conditions as the basis of the model of patriotism education of pupils in conditions of military lyceum based on the respective goals, approaches, principles, content, pedagogical conditions, criteria and expected results.

Methods. In determining the research problem, the theoretical methods for assessing the formation of patriotism of student youth are used: and the simulation of the education of patriotism among pupils in a military environment

Results.The model of upbringing patriotism of student youth in conditions of military lyceum in our study contains the following components: target (goal), conceptual (approaches, principles and functions of patriotism education of student youth in conditions of military lyceum), content component, operational-technological (pedagogical conditions for the upbringing of patriotism of student youth in conditions of military lyceum and the method of realization of pedagogical conditions) and a productive component.

The content components of patriotism education of pupils in the military lyceum include the following components: patriotic consciousness, a set of professional and personal qualities (moral-political, civil, military-professional, social-psychological, mental, physical), psychological, general-military and physical readiness.

The operational-technological component prevented pedagogical conditions for the education of patriotism of pupils in the conditions of the military lyceum as a set of reasons, 
circumstances, factors influencing a certain process and can accelerate or slow it, affecting it by the end result.

Creation in the military lyceum of the educational environment should provide for the student to open up the potential of patriotic education and launch its mechanisms. An important aspect of the implementation of this pedagogical condition can be considered measures of a coordinating nature, in particular involving the student youth in the types of patriotic activities of the military lyceum.

The use of the educational potential of educational subjects in order to raise the patriotism of student youth in conditions of the military lyceum is conditioned by the fact that the education of patriotism of the student is carried out mainly in the process of educational and cognitive activity by introducing value components into the contents of educational subjects (Ukrainian language and literature, Ukrainian history, Ukrainian culture, geography, defense of the Fatherland and others).

Regarding the third condition, as a content-methodological provision of the education of patriotism of student youth in the conditions of the military lyceum, we note that its implementation envisaged the development of a set of educational and special programs and methods for organizing and conducting activities for the education of patriotism of student youth in conditions of the military lyceum in its various forms, the use the whole variety of pedagogical forms and means taking into account peculiarities of pupils' life; regular publication of the relevant literature covering this area of activity, taking into account innovations, advanced educational experience.

The effective component included the criteria for patriotic education: cognitive, valuemotivational, productive-behavioral, which determined the level of formation of the patriotic upbringing of a pupil of a military lyceum.

Originalit. The scientific novelty and practical significance of the results of the study is determined by a significant increase in the role of the spiritual component in the functioning of military lyceums, modeling the process of raising patriotism among pupils in a military lyceum.

Conclusion. Thus, the formed patriotic upbringing is considered by us as a result of assimilation of pupils' youth in the conditions of the military lyceum of the experience of cognitive activity, emotional-valuable relations and practical and practical experience, which manifest themselves in the ability and readiness to be realized as a personality and individuality in activities for the benefit of the Motherland.

Thus, the pedagogical conditions for the education of patriotism of students in the military lyceum, which implement selected and structured content in practical form through a set of methods, forms and means, and is the basis of a particular model. All components of the model, in close relationship with each other, ensure the realization of the goal. Thus, the result of the implementation and implementation of the model proposed by us is a lyceum with an appropriate level of formation of patriotic education.

Prospects for further research are the definition of recommendations for the education of patriotism of student youth in conditions of military lyceum.

Key words: model; patriotism; patriotic education; love of the Motherland; military lyceum students; content. 